\title{
Cancer chemopreventive and antioxidant activities of seed, skin, and pulp of Maximo hybrid grapes (IAC 138-22) at five different ripening stages
}

\author{
Débora Rigamonti Gomes Cruz Freire $^{1}$ (D) Camile Zanichelli da Costa Cassiano ${ }^{1}$ (D) \\ Karla Lírio Soares ${ }^{1}$ (D) Mayara Fumiere Lemos $^{1}$ (D) Elisângela Flávia Pimentel-Schmitt ${ }^{1}$ (i) \\ Marcio Fronza ${ }^{1}$ (D) Denise Coutinho Endringer ${ }^{1}$ (i) Rodrigo Scherer $^{1^{*}}$ (i)
}

${ }^{1}$ Programa de Pós-graduação em Ciências Farmacêuticas, Universidade Vila Velha (UVV), 29102-920, Vila Velha, ES, Brasil. E-mail: rodrigo.scherer@uvv.br. ${ }^{*}$ Corresponding author.

\begin{abstract}
This study evaluated the composition and the cancer chemopreventive and antioxidant activities of the seed, skin, and pulp of Maximo hybrid grapes (IAC 138-22) harvested at different ripening stages. The content of total phenolic compounds and tannins were determined by the Folin-Ciocaulteau method, and total anthocyanins were determined using the differential $\mathrm{pH}$ method. Different chemical methods assessed the antioxidant activity. Cell viability (macrophage and melanoma skin cancer) and cancer chemopreventive activity were tested in cell lines by quinone reductase induction assay, $T N F$ - $\alpha$-induced $N F-\kappa B$ inhibitory activity assay, and aromatase inhibitory activity assay. The hybrid grape had high phenolic contents in both seeds and skin, significantly reduced upon ripening. The results showed that fruit ripening significantly affected both the composition and the antioxidant and cancer chemopreventive activities. Except for the anthocyanin content, the most significant results were observed for green seeds, with the greenest stage showing the best results. The green seeds showed the highest antioxidant activity, even when compared to free resveratrol. In the assessment of cancer chemopreventive activity, the green seeds showed the ability to inhibit $N-F \kappa B$ and aromatase activity, important factors for the early stage of cancer development. Besides, no extracts showed cytotoxicity. Therefore, this grape's green seeds showed strong antioxidant and cancer chemopreventive activities confirmed herein, suggesting beneficial health effects.
\end{abstract}

Key words: aromatase, antioxidant, grape, cancer chemopreventive.

Atividades quimiopreventiva de câncer e antioxidante de sementes, casca e polpa de uvas híbridas Maximo (IAC 138-22) em cinco diferentes estágios de maturação

RESUMO: $O$ objetivo deste estudo foi avaliar a composição e as atividades quimiopreventiva de câncer e antioxidante da semente, polpa e casca de uvas híbridas Maximo (IAC 138-22) colhidas em diferentes estágios de maturação. Os teores de compostos fenólicos totais, antocianinas e taninos foram determinados a partir dos extratos etanólicos. O conteúdo de fenólicos e taninos totais foi determinado pelo método de Folin-Ciocaulteau, e o teor de antocianinas totais foi determinado pelo método do $\mathrm{pH}$ diferencial. A atividade antioxidante foi avaliada por diferentes métodos químicos, e a viabilidade celular (macrófagos e melanomas), e atividade quimiopreventiva de câncer foi testada em culturas de células por ensaio de indução de quinona redutase, ensaio de atividade inibidora de NF- $\kappa B$ induzido por TNF- $\alpha$ e ensaio de atividade inibidora de aromatase. A uva hibrida apresentou alto teor de fenólicos nas sementes e na casca, teor que reduziu significativamente com o amadurecimento. Os resultados mostraram que o amadurecimento dos frutos afetou significativamente a composição $e$ as atividades antioxidantes e quimiopreventivas de câncer. Com exceção do teor de antocianinas, os resultados mais significativos foram observados para as sementes verdes, com o estádio mais verde apresentando os melhores resultados. As sementes verdes apresentaram a maior atividade antioxidante, mesmo quando comparadas ao resveratrol livre. Na avaliação da atividade quimiopreventiva do câncer, as sementes verdes mostraram capacidade de inibir a atividade do $N F-\kappa B$ e da aromatase, fatores importantes para o estágio inicial do desenvolvimento do câncer. Além disso, nenhum extrato apresentou atividade citotóxica. Portanto, as sementes verdes desta uva apresentam resultados promissores dadas as fortes atividades antioxidantes e quimiopreventivas do câncer aqui confirmadas, sugerindo efeitos benéficos à saúde.

Palavras-chave: aromatase, antioxidantes, uva, quimioprevenção de câncer.

\section{INTRODUCTION}

Grapes are popular worldwide, and their use is diverse. They can be consumed fresh, dehydrated, in wines, juices, jellies, dietary supplements, and ice cream, among other processed foods. Grapes comprise various nutrients, such as carbohydrates, proteins, vitamins, minerals, and dietary fibers. Additionally, they contain phytochemicals, such as phenolic compounds known to have numerous biological activities, e.g., anti-inflammatory, antimicrobial, antitumor, antioxidant, and particularly cancer 
chemopreventive activities (STEWARD \& BROWN, 2013; ACUÑA-AVILA et al., 2016;).

The use of natural, biological, or synthetic agents capable of suppressing, reversing, or preventing the early stages of carcinogenesis is known as cancer chemoprevention. These agents may also play a preventive role in the premalignant cells' progression (SPORN, 1976). It is also common knowledge that cancer is a chronic process determined by the uncontrolled growth of abnormal cells and that the global incidence of this disease has been increasing considerably, which arouses the interest for new prevention strategies (NCI, 2015).

Many studies on different grape species involved in beneficial health processes indicate that the genetic variability among species, including new hybrids, directly influences these effects since they have distinct compounds and agronomic characteristics (SILVA, et al., 2018, 2019; TECCHIO et al., 2020).

According to the Brazilian Agricultural Research Corporation (Empresa Brasileira de Pesquisa Agropecuária - EMBRAPA), there is a predominance of hybrid or American grapes in various producing regions. However, some Brazilian regions opt for exclusive Vitis vinifera cultivation even if their production corresponds to a lower percentage (MELLO, 2017).

Both the Brazilian Agricultural Research Corporation (EMBRAPA) and the Agronomic Institute of Campinas (IAC) developed, through studies on genetic improvement, the Maximo hybrid grape (IAC 138-22). This hybrid results from the crossing between Syrah (Vitis vinifera) and Seibel 11342 (hybrid) grapes, which intends to improve the resistance to pathogens and enhance the sensory quality of these hybrid grapes byproducts to the consumers. The current literature highlights that Maximo hybrid grapes (IAC 138-22) are from recent cultivation. However, previous studies have shown that this grape has relevant sensory characteristics and comprises promising compounds, thus inciting the study of their biological properties and potential applications, such as in flour, juices, and jellies (MORELLI \& PRADO, 2012; BIASOTO et al., 2014; FRAIGE; et al., 2014; MARTINS et al., 2016; SILVA, et al., 2019).

Evaluation of the Maximo hybrid grape composition has demonstrated that these grapes feature higher contents of individual and total anthocyanins, flavonols, t-resveratrol, and total phenolic compounds compared to other grape varieties (SILVA, et al., 2019). In another study on the presence of anthocyanins, the authors reported that cyanidin, peonidin, delphinidin, petunidin, and malvidin, mainly in the forms of glycosides and acyl glycosides, were the main compounds. Moreover,malvidin-3-glycoside is the most abundant in almost all grape varieties (FRAIGE et al. 2014).

Among the non-flavonoid compounds, phenolic acids stood out not only for contributing to the sensory characteristics but also by providing beneficial effects either by consuming the fresh fruit itself or its byproducts (FARHADI et al., 2016). A study by MORELLI \& PRADO (2012) indicated that grape jellies formulated with the Maximo variety (IAC 138-22) were considered good sources of antioxidant phenolic compounds. Another study on the evaluation of Maximo grape residue resulting from wine production demonstrated larger quantities of flavonoids and phenolic acids, as well as a more distinguished antioxidant activity than those reported in residues of other grape varieties (MARTINS et al., 2016).

Bearing in mind the economic importance of developing new hybrid grapes, the present study evaluated the composition, the cancer chemopreventive potential, and antioxidant activities of seed, pulp, and skin of Maximo hybrid grape (IAC 138-22) at different ripening stages.

\section{MATERIALS AND METHODS}

\section{Reagents}

Anhydrous sodium carbonate, gallic acid, 2,2-diphenyl-1-picrylhydrazyl (DPPH), 2,4,6-tri (2-pyridyl)-1,3,5-triazine (TPTZ), 2,2-azino bis3-ethylbenzothiazoline-6-sulfonic acid (ABTS), potassium persulfate, peroxidase, and resveratrol $\left(\mathrm{CAS} \mathrm{n}^{\circ}\right.$ 501-36-0; empirical formula: $\mathrm{C}_{14} \mathrm{H}_{12} \mathrm{O}_{3}$ molecular weight: 228.24) were obtained from Sigma-Aldrich $^{\circledR}$, St. Louis, USA. Hydrochloric acid, acetic acid, monobasic and dibasic potassium phosphates, and potassium chloride were acquired from Cromoline ${ }^{\circledR}$, Diadema, SP. Folin-Ciocaulteau reagent was obtained from Merck $^{\circledR}$, Darmstadt, Germany, and $99.5 \%$ ethanol from Quimex ${ }^{\circledR}$, Cotia, SP. Sodium acetate and ferric chloride were acquired from Dinâmica ${ }^{\circledR}$, Diadema, SP. Hydrogen peroxide and sodium hydroxide were purchased from Neon ${ }^{\circledR}$, São Paulo, SP. Phenol red was obtained from Synth ${ }^{\circledR}$, Diadema, SP.

\section{Samples}

The Maximo hybrid grapes (IAC 138-22) were grown on an espalier system, harvested weekly 
in a winery at the State of Espírito Santo, Brazil $\left(19^{\circ} 55^{\prime} 03.7^{\prime}\right.$ 'S, 4044'00.1' $\left.\mathrm{W}\right)$ at five different ripening stages. The date of the first sampling corresponded to the unripest stage of the fruit [Seed 1 (S1), Skin 1 (C1), Pulp 1 (P1)], while the last date of sampling corresponded to the ripest one [Seed 5 (S5), Skin 5 (C5), Pulp 5 (P5)] (Figure 1). The harvest was performed on both sides of the selected rows, averting the first two vines of each row ( $5 \mathrm{~kg}$ each). The grapes were washed with tap water and then in deionized water three times; they were then carefully separated manually into the skin, pulp, and seeds. Each fraction was frozen at $-80^{\circ} \mathrm{C}$ in an ultra-freezer (CL580-86V, Coldlab ${ }^{\circledR}$ ), freeze-dried (Enterprise I - Terroni ${ }^{\circledR}$ ), milled in a knife mill, and stored under refrigeration until analyzed.

\section{Extracts}

The extraction was performed using $20 \mathrm{~g}$ of freeze-dried material in $200 \mathrm{~mL}$ of $99.5 \%$ ethanol by the ultrasound-assisted maceration method (Elmasonic P $60 \mathrm{~Hz}-$ Elma $^{\circledR}$ ), according to the protocol described by GUSS et al. (2017), with some modifications. After two cycles of $30 \mathrm{~min}$, the extracts were filtered through filter paper twice. The organic fractions were pooled and evaporated in a rotary evaporator (Fisatom ${ }^{\circledR} 802-1200 \mathrm{~W}$ ) until ethanol was removed. The process was completed in the oven (TE $394 / 2 \mathrm{MP}, 1500 \mathrm{~W}-\mathrm{Tecnal}^{\circledR}$ ) at $40{ }^{\circ} \mathrm{C}$ for $24 \mathrm{~h}$, with subsequent freeze-drying for another $24 \mathrm{~h}$.

\section{Total phenolic compounds}

The content of total phenolic compounds was determined by the Folin-Ciocaulteau method, according to the methodology described by GUSS et al. (2017). Briefly, $30 \mu \mathrm{L}$ of the extracts in ethanol at a concentration of $0.5 \mathrm{mg} / \mathrm{mL}$ and $150 \mu \mathrm{L}$ of Folin reagent diluted in water $(1 / 10)$ were used. After 5 min, $120 \mu \mathrm{l}$ of $7 \%$ anhydrous sodium carbonate was added and allowed to react for $90 \mathrm{~min}$ in the dark. The reading was performed in an ELISA reader (Elisa Spectra count Packad - USA) at $740 \mathrm{~nm}$. Results were expressed in milligrams of gallic acid per gram of extract.

\section{Quantification of tannins}

To analyze the chemical components, $60 \mathrm{mg}$ of the skin, pulp, and seed extracts were weighed and transferred to a flat bottom flask containing $150 \mathrm{~mL}$ of carbon dioxide-free water after complete solubilization, according to the methodology described by KREPSKY et al. (2012), with adaptations. The flask was then kept in a water bath at $60{ }^{\circ} \mathrm{C}$ for $30 \mathrm{~min}$. The solution was filtered and transferred to a $250 \mathrm{~mL}$ volumetric flask that had its volume completed with carbon dioxide-free water; after discarding the first $50 \mathrm{~mL}$, this sample became solution A. Subsequently, $20 \mathrm{~mL}$ of solution A was removed, added to an Erlenmeyer flask with $0.2 \mathrm{~g}$ of Polyvinylpyrrolidone (PVPP), which was stirred for $60 \mathrm{~min}$. Then, the solution was filtered (solution B) and $25 \mu \mathrm{L}$ of solution A or B were transferred along with $10 \mu \mathrm{L}$ of Folin-Ciocaulteau reagent $(10 \%)$ and $215 \mu \mathrm{L}$ of sodium carbonate $(10.6 \% \mathrm{w} / \mathrm{v})$ into a 96-well microplate. The readings were taken at $715 \mathrm{~nm}$ after $3 \mathrm{~min}$, using water as blank. Gallic acid was used as standard. The tannin content was determined by subtracting the total polyphenol content (solution A) from the non-adsorbed polyphenol content (solution B).

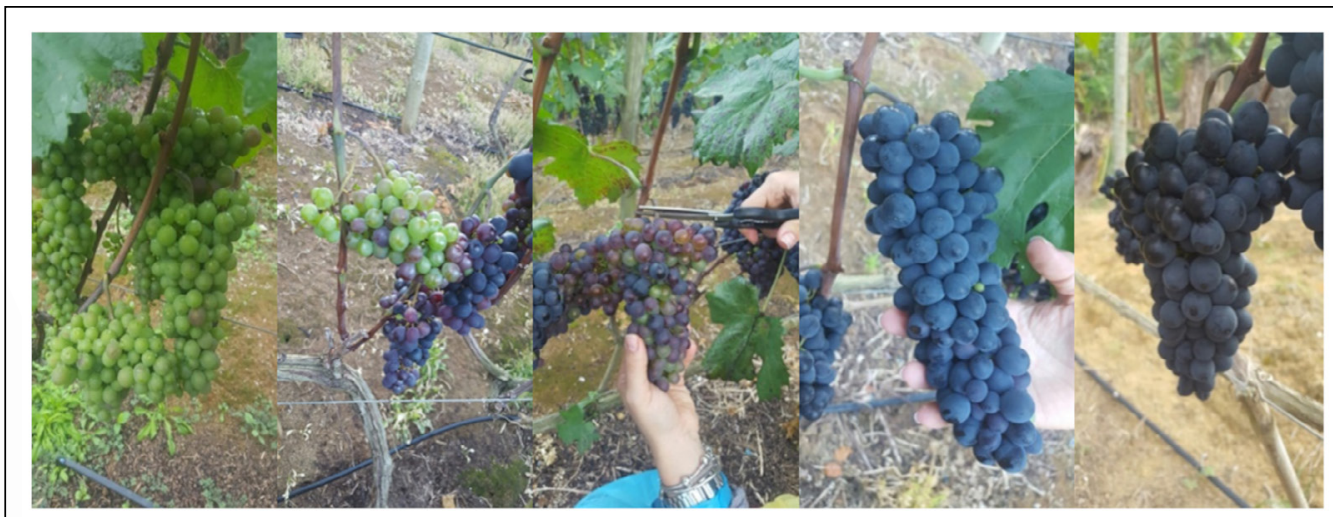

Figure 1 - Five different ripening stages of grapes in a winery in Santa Teresa - ES. 


\section{Total anthocyanins}

Total anthocyanins were determined using the differential $\mathrm{pH}$ method described by GIUSTI \& WROLSTAD (2001). Sample solutions $(5 \mathrm{mg} / \mathrm{mL})$ were prepared in two different buffers (potassium chloride $0.025 \mathrm{M}, \mathrm{pH} 1.0$; sodium acetate $0.4 \mathrm{M}$, $\mathrm{pH}$ 4.5). The absorbances of these extracts were monitored according to equation 1: $\mathrm{A}=(\mathrm{A} 520 \mathrm{~nm}-$ $\mathrm{A} 700 \mathrm{~nm}) \mathrm{pH} 1.0$ - (A520 nm - A700 nm) pH 4.5. The concentration ( $\mathrm{mg} \mathrm{g}^{-1}$ extract) of anthocyanins was expressed in cyanidin-3-glucoside equivalents and calculated using equation 2: $(\mathrm{A} \times \mathrm{MW} \times \mathrm{DF} \times 1000) /$ $(\varepsilon \times \mathrm{L})$, where $\mathrm{A}$ is obtained in equation 1 , MW is the molecular weight of cyanidin-3-glucoside, DF is the dilution factor, $\varepsilon$ is molar absorptivity $(26,900)$, and $\mathrm{L}$ is the optical path $(1 \mathrm{~cm})$.

\section{Antioxidant Activity}

\section{$D P P H$ free radical scavenging}

Samples' antioxidant activities were determined by the DPPH method, according to SCHERER \& GODOY (2009). The radical scavenging activity was calculated as follows: I $(\%)=\left[\left(\mathrm{Abs}_{0}-\right.\right.$ $\left.\left.\mathrm{Abs}_{1}\right) / \mathrm{Abs}_{0}\right] \times \mathrm{x}$ 100, where $\mathrm{Abs}_{0}$ is the absorbance of the blank and $\mathrm{Abs}_{1}$ is the absorbance in the presence of the test compound at different concentrations. The $\mathrm{IR}_{50}$ (concentration capable of reducing in $50 \%$ the free radicals) calculations demanded a linear range calibration curve by plotting the final concentration of the extract versus the corresponding scavenging effect. The antioxidant activity was expressed as the antioxidant activity index (AAI), calculated as follows: AAI = final concentration of DPPH $(\mu \mathrm{g} / \mathrm{mL}) /$ $\mathrm{IC}_{50}(\mu \mathrm{g} / \mathrm{mL})$. The AAI values were classified as: weak (AAI < 0.5), moderate (0.5-1.0), strong (1.0-2.0), and very strong (AAI > 2.0) antioxidant activities. The extracts' antioxidant activities were compared to that of the phenolic compound resveratrol.

\section{Ferric Reducing Antioxidant Power (FRAP) assay}

Antioxidant activity was based on the

FRAP method according to BENZIE \& STRAIN (1996), with some modifications. A mixture of 25 $\mathrm{mL}$ of sodium acetate trihydrate $(0.3 \mathrm{M}, \mathrm{pH} 3.6), 2.5$ $\mathrm{mL}$ of TPTZ solution $(10 \mathrm{mM} / \mathrm{L})$ in $40 \mathrm{mM} \mathrm{HCl}$, and $2.5 \mathrm{~mL}$ of aqueous ferric chloride $(20 \mathrm{mM})$ resulted in the FRAP reagent, immediately after preparation. Test aliquots of $30 \mu \mathrm{L}$ were added to a 96-well microplate, along with a $270 \mu \mathrm{L}$ FRAP reagent. For the blank, $30 \mu \mathrm{L}$ of ethanol was added. After reacting for $10 \mathrm{~min}$, the reading was performed at $595 \mathrm{~nm}$ using a microplate reader (SpectraMax 190 Microplate Reader, Molecular Devices, California,
USA). Calculations on antioxidant activity respected the following formula: I $(\%)=\left(\mathrm{Abs}_{1}-\mathrm{Abs}_{0}\right) \times 100$, where $\mathrm{Abs}_{0}$ is the blank and $\mathrm{Abs}_{1}$ is the absorbance of the tested extract. Results were expressed as $\mathrm{IR}_{50}$ (concentration capable of reducing $50 \%$ of the free radicals), calculated using the linear equation obtained from the calibration curve (final concentration $\mathrm{mg} / \mathrm{mL}$ versus $\mathrm{I} \%$ ). The extracts' antioxidant activities were compared to that of the phenolic compound resveratrol.

\section{ABTS free radical scavenging}

The antioxidant activity was determined according to RE et al. (1999), with modifications. The ABTS radical cation (ABTS ${ }^{\cdot+}$ ) was formed by the reaction among $7.0 \mathrm{mM}$ ABTS (in 50\% ethanol) and $2.45 \mathrm{mM}$ potassium persulfate (in distilled water), and stored under refrigeration for at least $24 \mathrm{~h}$. Before use, the reagent was diluted with $50 \%$ ethanol until the measured absorbance at $734 \mathrm{~nm}$ was $1.0( \pm 0.02)$. $\mathrm{ABTS}^{++}(270 \mu \mathrm{L})$ and the compounds $(30 \mu \mathrm{L}$ of each concentration) were added into 96-well microplates. The blank was $30 \mu \mathrm{L}$ of ethanol. After reacting for $10 \mathrm{~min}$ in the dark, the reading was performed at $734 \mathrm{~nm}$ using a microplate reader (SpectraMax 190 Microplate Reader, Molecular Devices, California, USA). The radical scavenging activity was calculated as follows: I $(\%)=\left[\left(\mathrm{Abs}_{0}-\mathrm{Abs}_{1}\right) / \mathrm{Abs}_{0}\right] \times 100$, where $\mathrm{Abs}_{0}$ is the absorbance of the blank and $\mathrm{Abs}_{1}$ is the absorbance in the presence of the test compound at different concentrations. The results were expressed as $\mathrm{IR}_{50}$ (concentration capable of reducing $50 \%$ of the free radicals) and calculated using a calibration curve in the linear range by plotting the final concentration of the extract versus the corresponding scavenging effect. The extracts' antioxidant activities were compared to that of the phenolic compound resveratrol.

\section{Hydrogen peroxide $\left(\mathrm{H}_{2} \mathrm{O}_{2}\right)$ assay}

Grapes' antioxidant activity at a concentration of $1000 \mu \mathrm{g} / \mathrm{mL}$ was also evaluated by the hydrogen peroxide scavenging method according to PICK \& KEISARI (1980), with modifications. In 96-well microplates, $25 \mu \mathrm{L}$ of the samples, 50 $\mu \mathrm{L}$ of $\mathrm{H}_{2} \mathrm{O}_{2}, 20 \mu \mathrm{L}$ of phenol red solution, $25 \mu \mathrm{L}$ of peroxidase enzyme, and $130 \mu \mathrm{L}$ phosphate buffer pH 7.0 were added. The microplates were incubated for $15 \mathrm{~min}$ in the dark, and the reaction ended after adding $25 \mu \mathrm{L}$ of $\mathrm{NaOH}(1.0 \mathrm{M})$. The reading was performed at $610 \mathrm{~nm}$, and the percentage of hydrogen peroxide reduction index (IR\%) was calculated by the following equation: IR $(\%)=[(\mathrm{AbsC}-\mathrm{AbsT}) / \mathrm{AbsC}]$ $\mathrm{x}$ 100], where $\mathrm{AbsC}$ is the control mean absorbance and AbsT is the test absorbance. The control reaction 
was performed in the absence of the sample, and the entire experiment was conducted in triplicate. The extracts' antioxidant activities were compared with that of the resveratrol.

\section{Cell viability assessment}

The MTT colorimetric method was used according to the methodology described by MOSMANN (1983) to investigate the cytotoxic activity. This method uses the metabolic reduction of 3-(4,5-dimethylthiazol-2-yl)-2,5diphenyltetrazolium bromide (MTT) by the enzyme succinate dehydrogenase within the cellular mitochondria, which forms a blue compound called formazan that, upon accumulation within the cell, is removed by dimethyl sulfoxide (DMSO). The method allows the determination of mitochondrial functionality of untreated cells and has been widely used to measure cell survival and functionality so that the number of living cells is proportional to the amount of produced formazan. In this study, two cell lines were used: RAW 264.7 macrophage and melanoma skin cancer (MV3). The cells were plated at a concentration of $7 \times 10^{4}$ cells $/ \mathrm{mL}$ in 96 -well plates and cultured with the extracts of the seeds, skin, and pulps of the Maximo hybrid grape at $100 \mu \mathrm{g} /$ $\mathrm{mL}$ for $24 \mathrm{~h}$. Samples were diluted in DMSO up to $0.5 \%$. Resveratrol was a positive control. After the 24-h incubation period, $100 \mu \mathrm{L}$ of MTT $(5 \mathrm{mg} / \mathrm{mL})$ was added to each well, and the formed formazan crystals dissolved in dimethyl sulfoxide (DMSO). The absorbance readings of the plates were made by an ELISA reader using 595-nm filters. Cell viability was expressed as a percentage.

\section{Cancer chemopreventive activity \\ In vitro quinone reductase induction assay}

Quinone reductase induction assay followed the method described by PROCHASKA \& SANTAMARIA (1988) and modified by GERHÄUSER et al. (1997). Rat hepatoma culture Hepa1c1c7 was used to evaluate the extracts as inducers of the enzyme quinone reductase. Grapeseed, skin, and pulp extracts were tested at $20 \mu \mathrm{g} / \mathrm{mL}$. Results were expressed as percentage inhibition (IR\%).

\section{$T N F-\alpha$-induced $N F-\kappa B$ inhibitory activity assay}

The assay was performed as described by HOMHUAL et al. (2006) with a $20 \mu \mathrm{g} / \mathrm{mL}$ extract. For the NF- $\kappa$ B inhibition assay, the $293-N F-\kappa B$ cell line (NF- $\kappa \mathrm{B}-$ luciferase transfected renal embryonic cells 293.12 PTA - 5554) was used after being cultured and induced by TNF- $\alpha(5 \mathrm{ng} / \mathrm{mL})$, and the Luc assay Promega ${ }^{\circledR}$ conveyed the reporter system. Na-tosylL-phenylalanine-chloromethyl ketone was used as positive control; $\mathrm{IC}_{50}=3.8 \mathrm{nM}$. The experiments were performed in triplicate. Results were expressed as percentage inhibition.

\section{Aromatase inhibitory activity assay}

The aromatase inhibition assay respected PEZZUTO et al. (2005). The effect of the extracts $(20 \mu \mathrm{g} / \mathrm{mL})$ on the aromatase enzyme was evaluated by detecting fluorescein produced when dibenzylfluorescein was hydrolyzed by the aromatase. Fluorescence was measured at $485 \mathrm{~nm}$ (excitation) and $530 \mathrm{~nm}$ (emission). A naringenin curve was used as a positive control $(74.46 \mu \mathrm{M}$ to $0.57 \mu \mathrm{M})$. Results were expressed as percentage inhibition.

\section{Statistical analyses}

Two-way analysis of variance (ANOVA) and Tukey's post hoc test were used to, respectively, determine if there was a significant difference between the means and the magnitude of this difference $(\mathrm{P}<$ $0.05)$. The data are parametric and expressed as mean \pm standard deviation values. Pearson's correlation coefficient was used to measure the degree of correlation between two metric variables. Biostat 5.0 software was used.

\section{RESULTS}

\section{Yield, total phenolics, anthocyanins, and tannins}

Table 1 presents extracts'e total yield and the contents of total phenolics, anthocyanins, and tannins. The extract yield was higher in Skin 1 (25.5\%) and lower in Pulp 3 (11.9\%).

The total phenolic content was significantly higher $(\mathrm{P}<0.05)$ in seeds than in skin and pulp. Seed samples presented a significant difference between each other $(\mathrm{P}<0.05)$, with the ripening stage being inversely proportional to the content of total phenolics, i.e., the riper the grapes, the lower the phenolic content. Skin 1 presented significantly higher phenolic content than others skin samples $(\mathrm{P}<0.05)$. No significant difference $(\mathrm{P}>0.05)$ in the phenolic content was reported between pulp samples.

Although, the anthocyanin content was evaluated in seeds, pulp, and skin, this class of phenolic pigments was reported only in the skin, as shown in table 1 . The anthocyanin content was significantly higher in Skin $5(\mathrm{P}<0.05)$, which corresponded to the ripest stage, whereas the lowest content was found in the completely unripe stage, as expected. 
Table 1 - Yield and contents of total phenolics, anthocyanins, and tannins in Maximo hybrid grape (IAC 138-22) extracts.

\begin{tabular}{|c|c|c|c|c|}
\hline & Yield (\%) & $\begin{array}{c}\mathrm{TPC}^{*} \\
\text { (mg GA/g extract) }\end{array}$ & $\begin{array}{l}\text { Anthocyanins } \\
\text { (mg/g extract) }\end{array}$ & $\begin{array}{c}\text { Tannins } \\
\text { (mg GA/100g extract) }\end{array}$ \\
\hline Seed 1 & 19.5 & $217.2 \pm 1.9 \mathrm{a}$ & ND & $26.1 \pm 0.22 \mathrm{a}$ \\
\hline Seed 2 & 20.1 & $187.0 \pm 7.0 \mathrm{~b}$ & ND & $21.0 \pm 1.4 b$ \\
\hline Seed 3 & 16.7 & $153.1 \pm 2.2 \mathrm{c}$ & ND & $16.0 \pm 0.44 \mathrm{c}$ \\
\hline Seed 4 & 15.8 & $143.7 \pm 1.9 \mathrm{~d}$ & ND & $15.2 \pm 0.3 \mathrm{c}$ \\
\hline Seed 5 & 12.3 & $132.5 \pm 0.5 \mathrm{e}$ & ND & $14.3 \pm 0.1 \mathrm{c}$ \\
\hline Skin 1 & 25.5 & $51.0 \pm 3.7 \mathrm{f}$ & ND & $1.6 \pm 0.4 \mathrm{e}$ \\
\hline Skin 2 & 23.3 & $27.9 \pm 1.3 \mathrm{~g}$ & $2.9 \pm 0.5 \mathrm{~d}$ & $1.2 \pm 0.4 \mathrm{e}$ \\
\hline Skin 3 & 24.3 & $16.7 \pm 0.4 \mathrm{~h}$ & $63.1 \pm 1.2 \mathrm{c}$ & $1.8 \pm 0.2 \mathrm{e}$ \\
\hline Skin 4 & 24.4 & $19.8 \pm 2.0 \mathrm{~h}$ & $81.9 \pm 0.2 b$ & $2.4 \pm 0.4 \mathrm{~d}$ \\
\hline Skin 5 & 23.2 & $18.9 \pm 1.6 \mathrm{~h}$ & $83.9 \pm 0.5 \mathrm{a}$ & $2.3 \pm 0.4 \mathrm{~d}$ \\
\hline Pulp 1 & 22.6 & $0.4 \pm 0.1 \mathrm{i}$ & ND & ND \\
\hline Pulp 2 & 17.2 & $1.1 \pm 0.3 \mathrm{i}$ & ND & ND \\
\hline Pulp 3 & 11.9 & $1.2 \pm 0.3 \mathrm{i}$ & ND & ND \\
\hline Pulp 4 & 18.8 & $1.7 \pm 0.0 \mathrm{i}$ & ND & ND \\
\hline Pulp 5 & 20.8 & $1.6 \pm 0.1 \mathrm{i}$ & ND & ND \\
\hline
\end{tabular}

*TPC: Total phenolic content. ND: not detected. Different letters in the same column represent significant differences $(\mathrm{P}<0.05)$. GA: gallic acid.

The tannin content was significantly higher $(\mathrm{P}<0.05)$ in seeds than in skin, regardless of the ripening stage, and no tannin was detected in the pulp. Seed 1 had the highest tannin content, while Skin 2 had the lowest, showing no statistical difference compared to Skins 1 and 3.

\section{Antioxidant activity}

The antioxidant activity of Maximo hybrid grape (IAC 138-22) extracts and free resveratrol were evaluated by distinct methods to investigate different antioxidant characteristics of the samples. AAI (antioxidant activity index) represented the DPPH free radical scavenging activity, and the free radical sequestration methods ABTS and FRAP were represented by $\mathrm{IR}_{50}$ (sample quantity required to decrease the initial radical concentration by $50 \%$ ). Unlike the methods mentioned above, the hydrogen peroxide scavenging method was expressed as $\mathrm{I} \%$ (percentage of $\mathrm{H}_{2} \mathrm{O}_{2}$ inhibition index).

Seed extracts showed relevant antioxidant activity by the DPPH free radical scavenging method. Besides, the seed AAI values at all ripeness levels were significantly higher $(\mathrm{P}<0.05)$ than that of resveratrol (Table 2). Moreover, the AAI decreased with grape ripening in both seeds and skin, indicating a possible relationship with the total phenolic content. Conversely, antioxidant activity was classified as moderate in Skin 1 (AAI between 0.5 and 1.0) but weak in the other skin samples. That reduced the content of total phenolic compounds.

The FRAP method showed no significant difference among the activities of Seeds 1 and 2 extracts compared to resveratrol, confirming its remarkable antioxidant activity. Furthermore, riper grapes denoted a significant reduction in activity (increase in $\mathrm{IR}_{50}$ ) (Table 2).

The antioxidant activity determined by the ABTS method showed similar results, with seed extracts presenting significantly higher antioxidant activity than skin extracts $(\mathrm{P}<0.05)$. Moreover, the antioxidant activity decreased with grape ripening (an increase of $\mathrm{IR}_{50}$ ) in both seeds and skin. Conversely, even though the seed extracts presented notable antioxidant activity as indicated by this method, resveratrol showed significantly higher activity.

Testing the antioxidant activity by the hydrogen peroxide $\left(\mathrm{H}_{2} \mathrm{O}_{2}\right)$ method showed that the percentage of inhibition index (I\%) was significantly higher in Seeds 1 and 2, confirming that green seeds have high antioxidant activity. The skin showed low activity and no significant difference $(P>0.05)$ by this method. Results also showed that, regardless of the ripening stage, grape pulp presented negligible antioxidant activity in all evaluated methods, as shown in table 3 . 
Table 2 - Antioxidant activities of Maximo hybrid grape (IAC 138-22) extracts determined by the DPPH, FRAP, ABTS, and $\mathrm{H}_{2} \mathrm{O}_{2}$ methods.

\begin{tabular}{|c|c|c|c|c|}
\hline & $\begin{array}{c}\text { DPPH } \\
\left(\mathrm{AAI}^{1}\right)\end{array}$ & $\begin{array}{l}\text { FRAP } \\
\left(\mathrm{IR}_{50}\right)^{2}\end{array}$ & $\begin{array}{l}\mathrm{ABTS}^{\bullet} \\
\left(\mathrm{IR}_{50}\right)^{2}\end{array}$ & $\begin{array}{l}\mathrm{H}_{2} \mathrm{O}_{2} \\
(\mathrm{I} \%)^{3}\end{array}$ \\
\hline Seed 1 & $4.7 \pm 0.0 \mathrm{a}$ & $5.1 \pm 0.5 \mathrm{a}$ & $5.3 \pm 0.4 b$ & $69.3 \pm 1.0 \mathrm{~b}$ \\
\hline Seed 2 & $4.5 \pm 0.1 b$ & $5.3 \pm 0.1 \mathrm{a}$ & $5.6 \pm 0.1 b$ & $72.1 \pm 1.3 b$ \\
\hline Seed 3 & $3.6 \pm 0.0 \mathrm{c}$ & $7.6 \pm 0.1 b$ & $7.9 \pm 0.5 c$ & $9.0 \pm 0.1 \mathrm{~d}$ \\
\hline Seed 4 & $3.2 \pm 0.0 \mathrm{~d}$ & $11.0 \pm 0.2 \mathrm{c}$ & $11.9 \pm 1.0 \mathrm{~d}$ & $5.8 \pm 2.4 \mathrm{de}$ \\
\hline Seed 5 & $3.3 \pm 0.0 \mathrm{~d}$ & $10.8 \pm 0.9 \mathrm{c}$ & $9.5 \pm 0.5 c$ & $9.3 \pm 3.8 \mathrm{~d}$ \\
\hline Skin 1 & $0.8 \pm 0.0 \mathrm{f}$ & $23.8 \pm 0.6 \mathrm{~d}$ & $50.0 \pm 2.9 \mathrm{e}$ & $2.1 \pm 0.6 \mathrm{e}$ \\
\hline Skin 2 & $0.4 \pm 0.0 \mathrm{~g}$ & $45.8 \pm 0.2 \mathrm{e}$ & $72.3 \pm 0.5 f$ & $1.7 \pm 0.1 \mathrm{e}$ \\
\hline Skin 3 & $0.2 \pm 0.0 \mathrm{~h}$ & $98.1 \pm 2.3 \mathrm{~g}$ & $144.8 \pm 10.1 \mathrm{~g}$ & $4.1 \pm 0.5 \mathrm{e}$ \\
\hline Skin 4 & $0.3 \pm 0.0 \mathrm{~h}$ & $78.2 \pm 1.5 \mathrm{f}$ & $130.6 \pm 3.8 \mathrm{~g}$ & $5.2 \pm 1.1 \mathrm{de}$ \\
\hline Skin 5 & $0.3 \pm 0.0 \mathrm{~h}$ & $65.4 \pm 2.1 f$ & $126.2 \pm 8.9 \mathrm{~g}$ & $4.1 \pm 0.2 \mathrm{e}$ \\
\hline Pulp 1 & $<0.01$ & $729.6 \pm 13 \mathrm{~h}$ & $>1000$ & NA \\
\hline Pulp 2 & $<0.01$ & $>1000$ & $>1000$ & NA \\
\hline Pulp 3 & $<0.01$ & $>1000$ & $>1000$ & NA \\
\hline Pulp 4 & $<0.01$ & $>1000$ & $>1000$ & NA \\
\hline Pulp 5 & $<0.01$ & $>1000$ & $>1000$ & NA \\
\hline Resveratrol & $1.5 \pm 0.1 \mathrm{e}$ & $5.6 \pm 0.6 \mathrm{a}$ & $3.3 \pm 0.0 \mathrm{a}$ & $86.8 \pm 2.3 a$ \\
\hline
\end{tabular}

${ }^{1}$ Antioxidant activity index. ${ }^{2}$ Results are expressed in $\mu \mathrm{g} / \mathrm{mL}$. Different letters in the same column represent significant differences $(\mathrm{P}<$ 0.05). ${ }^{3}$ Extracts evaluated at the concentration of $1000 \mu \mathrm{g} / \mathrm{mL}$ and resveratrol at the concentration of $250 \mu \mathrm{g} / \mathrm{mL}$. NA: no activity.

Correlation analyses were performed to assess the contribution of total phenolic compounds and anthocyanins to grapes' antioxidant activity. The total phenolic content of seed and skin extracts showed positive correlations with the antioxidant activity obtained through all methods, except for the hydrogen peroxide scavenging one, which showed a moderate correlation, as observed in table 3 and table 4. Despite the lack of significant correlation between the anthocyanin content in the skin and antioxidant activity as determined by the DPPH, ABTS, and FRAP methods, the anthocyanins present in the skin showed a strong correlation with the hydrogen peroxide inhibition method $(r=0.95)$ (Table 4). Thus, the anthocyanin activity could be more effective in $\mathrm{H}_{2} \mathrm{O}_{2}$ scavenging than in the other evaluated mechanisms. The correlation test for skin samples also showed a moderate negative correlation $(\mathrm{r}=-0.79)$ between the total anthocyanin and phenolic contents. Conversely, a strong correlation was reported between the phenolic content and the antioxidant activity by the DPPH, ABTS, and FRAP methods, which could suggest that the antioxidant activity of the skin is strongly correlated with other phenolics reported in the skin, but not with the presence of anthocyanins.

\section{Cell viability}

To assess the effects of the extracts of Maximo hybrid grape seeds, skin, and pulp, at different ripening stages, on cell viability, in vitro MTT colorimetric assay with two cell lines, RAW 264.7 macrophages and skin cancer cells - MV3 (melanoma), was conducted at $100 \mu \mathrm{g} / \mathrm{mL}$. None of the investigated extracts presented a cytotoxic effect

Table 3 - Correlation matrix for grape seed samples.

\begin{tabular}{lcccc}
\hline & $\mathrm{TPC}^{1}$ & $\mathrm{AAI}^{2}$ & $\mathrm{H}_{2} \mathrm{O}_{2}$ & ABTS \\
\hline TPC & - & & & \\
$\mathrm{AAI}$ & 0.95 & - & & \\
$\mathrm{H}_{2} \mathrm{O}_{2}$ & 0.77 & 0.90 & - & - \\
$\mathrm{ABTS}$ & -0.82 & -0.94 & -0.83 & -9.95 \\
FRAP & -0.86 & -0.95 & -0.85 & - \\
\hline
\end{tabular}

${ }^{1}$ Total phenolic content. ${ }^{2}$ Antioxidant activity index. 
Table 4 - Correlation matrix for grape skin samples.

\begin{tabular}{lccccc}
\hline & $\mathrm{TPC}^{1}$ & $\mathrm{ACY}^{2}$ & $\mathrm{AAI}^{3}$ & $\mathrm{H}_{2} \mathrm{O}_{2}$ & ABTS \\
\hline $\mathrm{TFC}$ & - & & & & \\
$\mathrm{ACY}$ & -0.79 & - & & & \\
$\mathrm{AAI}$ & 0.99 & -0.71 & - & - & - \\
$\mathrm{H}_{2} \mathrm{O}_{2}$ & -0.70 & 0.95 & -0.61 & 0.88 & -0.96 \\
$\mathrm{ABTS}$ & -0.92 & 0.92 & -0.89 & 0.79 & - \\
FRAP & -0.90 & 0.79 & -0.91 & & 0.96 \\
\hline
\end{tabular}

${ }^{1}$ Total phenolic content. ${ }^{2}$ Total anthocyanin content. ${ }^{3}$ Antioxidant activity index.

on the tested strains (Figure 2). The discovery of novel toxicity-free agents with low side effects remains the main objective of cancer chemoprevention efforts (PEZZUTO et al., 2005). Therefore, all subsequent in vitro assays were performed at concentrations $\leq$ $100 \mu \mathrm{g} / \mathrm{mL}$. Resveratrol, used as a positive control, showed $96.5 \%$ and $42.6 \%$ of cell viability for the macrophage strain and $\mathrm{MV} 3$, respectively, at a concentration of $100 \mu \mathrm{g} / \mathrm{mL}$.

\section{Cancer chemoprevention}

The National Cancer Institute (NCI), based on empirical evidence, advocated that cancer chemopreventive trials should be conducted at a concentration of $20 \mu \mathrm{g} / \mathrm{mL}$, as higher concentrations could lead to undesirable health effects. Following these recommendations, experiments to induce quinone reductase, TNF- $\alpha$-induced NF- $\kappa$ B inhibitory activity, and aromatase inhibitory activity were conducted. All extracts showed baseline inhibition of quinone reductase. However, this value should be at least twice the value reported for basal metabolism to indicate activity (PROCHASKA; SANTAMARIA, 1988; GERHÄUSER et al., 1997).

Nevertheless, the values reported in the NF- $\kappa \mathrm{B}$ inhibition assay are noteworthy: 24.1 (Skin 2), 22.7 (Seed 3), and 19.0 (Seed 2) (Table 5). The outcome is promising because, in future studies, active compounds, such as cyanidin, malvidin, delphinidin, petunidin, and other anthocyanins, can be isolated from such crude extracts, enhancing their activity. Regarding the aromatase inhibition, the

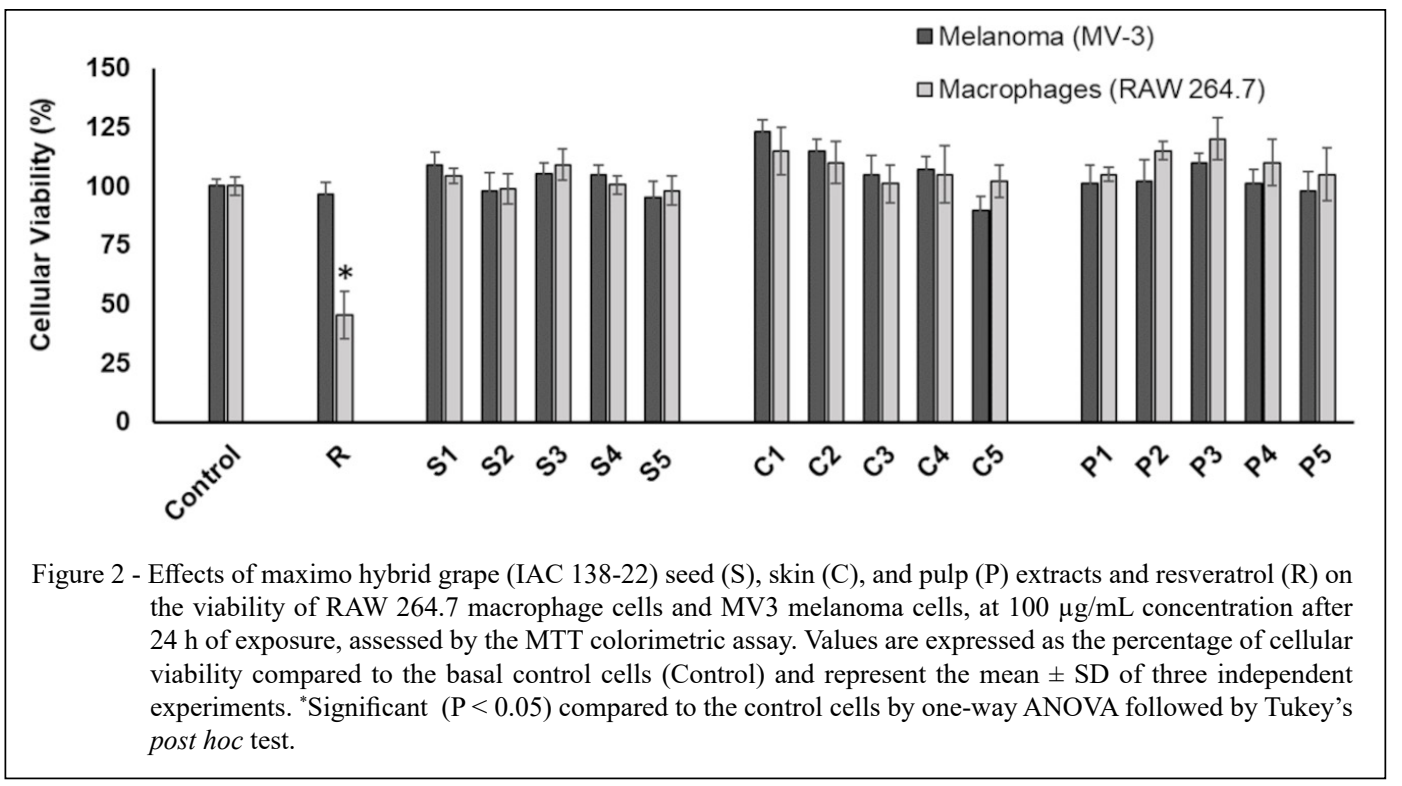

Ciência Rural, v.52, n.3, 2022. 
Table 5 - Cancer chemoprevention of Maximo hybrid grape (IAC 138-22) extracts.

\begin{tabular}{|c|c|c|c|}
\hline & $\mathrm{QR}^{\#}$ Index & $\%$ NFא-B inhibition & $\%$ Aromatase inhibition \\
\hline Seed 1 & $1 \pm 0.0$ & 0.0 & $5.0 \pm 0.0$ \\
\hline Seed 2 & $1 \pm 0.0$ & $19.0 \pm 0.0$ & $13 \pm 0.0$ \\
\hline Seed 3 & $1 \pm 0.0$ & $22.7 \pm 0.0$ & $68 \pm 0.0$ \\
\hline Seed 4 & $1 \pm 0.0$ & 0.0 & 0.0 \\
\hline Seed 5 & $1 \pm 0.0$ & 0.0 & 0.0 \\
\hline Skin 1 & $1 \pm 0.0$ & $7.9 \pm 0.0$ & 0.0 \\
\hline Skin 2 & $1 \pm 0.0$ & $24.1 \pm 0.0$ & 0.0 \\
\hline Skin 3 & $1 \pm 0.0$ & 0.0 & 0.0 \\
\hline Skin 4 & $1 \pm 0.0$ & 0.0 & 0.0 \\
\hline Skin 5 & $1 \pm 0.5$ & 0.0 & 0.0 \\
\hline Pulp 1 & $1 \pm 0.0$ & 0.0 & $48.0 \pm 0.0$ \\
\hline Pulp 2 & $1 \pm 0.2$ & 0.0 & 0.0 \\
\hline Pulp 3 & $1 \pm 0.0$ & $3.7 \pm 0.0$ & 0.0 \\
\hline Pulp 4 & $1 \pm 0.0$ & $6.5 \pm 0.0$ & 0.0 \\
\hline Pulp 5 & $1 \pm 0.0$ & $7.7 \pm 0.0$ & 0.0 \\
\hline
\end{tabular}

\#QR: Quinone Reductase. The extract concentration was $20 \mu \mathrm{g} / \mathrm{mL}$. The results were expressed in \% of inhibition.

most promising results were found again for Seed $3(68 \%)$, followed by Skin 1 (48\%), Seed 2 (13\%), and Seed $1(5 \%)$. Seed 3 had a significant value of aromatase inhibition compared to other grape extracts in different ripening stages (PEZZUTO et al., 2005). As mentioned before, the outcome is promising since these are crude extracts from which active compounds could be isolated in future studies. Therefore, green grape seeds may be a possible alternative to be explored as a source of cancer chemoprevention products.

\section{DISCUSSION}

Grapes are relevant sources of polyphenols for the human diet. The occurrence and content of these bioactive compounds in grape skin, pulp, and seeds can be affected by several factors. FARHADI et al. (2016) reporteddifferent grape cultivars and parts affected both phenolic content and antioxidant properties. Previous studies have also reported that grape seed extracts had a higher content of phenolic compounds and antioxidant activity when compared to skin extracts, corroborating the present study results (SANTOS et al., 2011).

Fruit ripening is another factor that can alter the phenolic composition of grapes. XIAO et al. (2018) reported that the amount of these phenolic substances decreased with grape ripening, with the largest accumulation of phenolic compounds being observed in the unripe grape, also corroborating the results of the present study. In other studies, grape seeds showed significantly reduced contents of catechins, procyanidins, and flavanones upon ripening (FERRER-GALLEGO et al., 2010; RODRÍGUEZPULIDO et al., 2012).

RODRÍGUEZ-PULIDO et al. (2012) reported that more than 20 phenolic compounds found in different grape varieties decreased in content during ripening in the seeds of Spain's Vitis vinifera, which is related to the polymerization reactions that occur during this process. These polymerization reactions may explain the decrease in phenolics during seed ripening (DOWNEY; et al., 2003).

As stated by GOWRISANKAR \& CLARK, (2016), the relationship between reactive oxygen species (ROSs) and free radicals is well established for cellular damage and aging-related diseases, just as the effects and benefits of natural antioxidants have been extensively explored over the past years. In agreement with these data, many studies have indicated that diseases such as cancer, cardiovascular disease (CVD), and aging are associated with oxidative stress caused by the imbalance between oxidants and antioxidants in the body (FARHADI et al., 2016). The strong antioxidant activity demonstrated in the present research suggested possible beneficial health effects, mainly 
arising from the seeds of Maximo grapes. It could reduce the oxidative damage that can cause certain types of cancer and degenerative diseases.

The selective inhibition of the aromatase enzyme is a relevant target trait in searching for cancer chemopreventive agents that can act against hormonedependent cancer (PEZZUTO et al., 2005). Here, Seed 3 showed $68 \%$ of aromatase inhibition, indicating that the crude extract contains some bioactive substances that inhibit this enzyme. Therefore, it is necessary to isolate these substances to expand the investigations. A previous study has shown the efficacy of grape seed extracts combined with resveratrol (obtained from bioactive grape compounds) in preventing and/ or treating colon cancer (REDDIVARI et al., 2016). Another study produced a biocompatible chitosan matrix loaded with grape seed extracts that increased the antitumor effect, suggesting a possible innovative drug (IANNONE et al., 2017). KIJIMA et al. (2006) demonstrated that grape seed extracts containing procyanidin dimers were potent inhibitors of aromatase enzymatic activity, suppressing estrogen production in breast cancer. Then, they managed to prove that the consumption of grape seed extracts suppressed the in vivo growth of aromatase-expressing breast tumors. The inhibitory activity over NF- $\kappa \mathrm{B}$ is also noteworthy since it activates the innate immune response. $\mathrm{NF}-\mathrm{\kappa B}$ is a transcription factor related to the development and progression of cancer, giving resistance of pre-neoplastic cells to the mechanism of cellular apoptosis (Karin, 2006). Thus, the Skin 2, Seed 3, and Seed 2 samples showed promising cancer chemopreventive activity, acting in the stage of promotion and progression of carcinogenesis.

The seeds showed the strongest antioxidant activity, even when compared to free resveratrol. Furthermore, in the assessment of cancer chemopreventive activity, the seeds presented relevant inhibition in the $\mathrm{NF}-\mathrm{\kappa B}$ and aromatase inhibition assay, given promising results for cancer chemopreventive, suggesting beneficial health effects. The main limitations of the present research were the incomplete characterization of grape seed and the isolation of substances, such as those present in green seeds. These substances could have significantly higher activity when isolated from the crude extract.

\section{ACKNOWLEDGEMENTS}

The Fundação de Amparo à Pesquisa do Espírito Santo (FAPES) and the Coordenação de Aperfeiçoamento de Pessoal de Nível Superior (CAPES), and The Conselho Nacional de Desenvolvimento Científico e Tecnológico do Brasil (CNPq), PQ-process \#310489/20199 are greatly acknowledged for financial support.

\section{DECLARATION OF CONFLICT OF INTEREST}

The authors declare no conflict of interest.

\section{AUTHORS' CONTRIBUTIONS}

All authors contributed equally for the conception of the study and writing of the manuscript. All authors critically revised the manuscript and approved the final version.

\section{REFERENCES}

ACUÑA-AVILA, P. E. et al. Relationship between the elemental composition of grapeyards and bioactive compounds in the Cabernet Sauvignon grapes Vitis vinífera harvested in Mexico. Food Chemistry, 2016. v.203, p.79-85. Available from: $<$ https:// doi.org/10.1016/j.foodchem.2016.02.031>. Accessed: Jun. 28, 2021.

BENZIE, I. F. F., STRAIN, J. J. The Ferric Reducing Ability of Plasma (FRAP) as a Measure of "“Antioxidant Power"”: The FRAP Assay. Analytical Biochemistry, 1996. v.239, p.70-76. Available from: <https://doi.org/10.1006/abio.1996.0292>. Accessed: Jun. $28,2021$.

BIASOTO, A. C. T. et al. Acceptability and preference drivers of red wines produced from Vitis labrusca and hybrid grapes. Food Research International, 2014. v.62, p.456-466. Available from: $<\mathrm{http} / / \mathrm{dx}$. doi. org/10.1016/j.foodres.2014.03.052>. Accessed: Jun. 28, 2021.

DOWNEY, M. O.; et al.,. Analysis of tannins in seeds and skins of Shiraz grapes throughout berry development. Australian Journal of Grape and Wine Research, 2003. v.9, n.1, p.15-27. Available from: $\quad<$ https://doi.org/10.1111/j.1755-0238.2003.tb00228.x>. Accessed: Jun. 28, 2021.

FARHADI, K. et al. Determination of phenolic compounds content and antioxidant activity in skin, pulp, seed, cane and leaf of five native grape cultivars in West Azerbaijan province, Iran. Food Chemistry, 2016. v.199, p.847-855. Available from: $<$ http://dx.doi. org/10.1016/j.foodchem.2015.12.083>. Accessed: Jun. 28, 2021.

FERRER-GALLEGO, R. et al. Statistical correlation between flavanolic composition, colour and sensorial parameters in grape seed during ripening. Analytica Chimica Acta, 2010. v.660, n.1-2, p. 22-28. Available from: <https://doi.org/10.1016/j. aca.2009.09.039>. Accessed: Jun. 28, 2021.

FRAIGE, K.; et al., Fingerprinting of anthocyanins from grapes produced in Brazil using HPLC-DAD-MS and exploratory analysis by principal component analysis. Food Chemistry, 2014. v.145, p.395-403. Available from: <http://dx.doi.org/10.1016/j. foodchem.2013.08.066>. Accessed: Jun. 28, 2021.

GERHÄUSER, C. et al. Cancer chemopreventive potential of sulforamate, a novel analogue of sulforaphane that induces phase 2 drug-metabolizing enzymes. Cancer Research, 1997. v.57, p.272-278. Available from: <https://cancerres.aacrjournals.org/ content/57/2/272.long>.Accessed: Jun. 28, 2021.

GIUSTI, M. M.; WROLSTAD, R. E. Characterization and Measurement of Anthocyanins by UV-Visible Spectroscopy. Food Analytical Chemistry, 2001. p.1-13. Available from: $<$ https://doi. org/10.1002/0471142913.faf0102s00>. Accessed: Jun. 28, 2021. 
GOWRISANKAR, Y. V.; CLARK, M. A. Angiotensin II induces interleukin-6 expression in astrocytes: Role of reactive oxygen species and NF- $\mathrm{\kappa B}$. Molecular and Cellular Endocrinology, 2016. v.437, p.130-141. Available from: <http://dx.doi. org/10.1016/j.mce.2016.08.013>. Accessed: Jun. 28, 2021.

GUSS, K. L. et al. Ultrasound-assisted extraction of Achyrocline satureioides prevents contrast-induced nephropathy in mice. Ultrasonics Sonochemistry, 2017. v.37, p.368-374. Available from: $<$ http://dx.doi. org/10.1016/j.ultsonch.2017.01.035>. Accessed: Jun. 28, 2021.

HOMHUAL, S. et al. Bioactive dammarane triterpenes from the mangrove Plant Bruguiera gymnorrhiza. Journal of Natural Products, 2006. v.69, n.3, p.421-424. Available from: $<$ https://doi. org/10.1021/np058112x>.Accessed: Jun. 28, 2021.

IANNONE, M. et al. Characterization and in vitro anticancer properties of chitosan-microencapsulated flavan-3-ols-rich grape seed extracts International Journal of Biological Macromolecules, 2017 v.104, p.1039-1045. Available from: <http://dx.doi.org/10.1016/j. ijbiomac.2017.07.022>. Accessed: Jun. 28, 2021.

KARIN, M. NF-kB and cancer: Mechanisms and Targets. Molecular Carcinogenesis, 2006. v.45, p.355-361. Available from: <https:// doi.org/10.1002/mc.20217>.Accessed: Jun. 28, 2021.

KIJIMA, I. et al. Grape seed extract is an aromatase inhibitor and a suppressor of aromatase expression. Cancer Research, 2006. v.66, n.11, p.5960-5967. Available from: <https://cancerres. aacrjournals.org/content/66/11/5960>. Accessed: Jun. 28, 2021.

KREPSKY, P. B. et al. Phytomedicine chemical composition and vasodilatation induced by Cuphea carthagenensis preparations. Phytomedicine, 2012. v.19, p.953-957. Available from: <https:// doi.org/10.1016/j.phymed.2012.05.011>. Accessed: Jun. 28, 2021.

MARTINS, I. M. et al. Enzymatic biotransformation of polyphenolics increases antioxidant activity of red and white grape pomace. Food Research International, 2016. v.89, p.533-539. Available from: <http://dx.doi.org/10.1016/j. foodres.2016.09.009>. Accessed: Jun. 28, 2021.

MELLO, L. M. R. De. Vitivinicultura brasileira: panorama 2016. EMBRAPA Uva e Vinho - Comunicado Técnico, 2017. v.199, p.1-7.

MORELLI, L. L. L.; PRADO, M. A. Extraction optimization for antioxidant phenolic compounds in red grape jam using ultrasound with a response surface methodology. Ultrasonics Sonochemistry, 2012. v.19, p.1144-1149. Available from: $<$ https://doi.org/10.1016/j. ultsonch.2012.03.009>. Accessed: Jun. 28, 2021

MOSMANN, T. Rapid colorimetric Assay for Cellular Growth and Survival: Application to Proliferation and Cytotoxicity Assays. Journal of Immunological Methods, 1983. v.65, p.55-63.

NCI, N. C. I. Cancer. [S.1.], 2015. Available from: $<$ https://doi. org/10.1016/0022-1759(83)90303-4>.Accessed: Jun. 28, 2021.

PEZZUTO, J. M. et al. Characterization of natural Product Chemopreventive Agents. Cancer Chemoprevention, 2005. v. 2 , n. 2 , p. 3-37. Available from: <https://link.springer.com/ chapter/10.1007/978-1-59259-768-0_1>. Accessed: Jun. 28, 2021.

PICK, E.; KEISARI, Y. A simple colorimetric method for the measurement of hydrogen peroxide produced by cells in culture. Journal oflmmunological Methods, 1980. v.38, p.161-170.
Available from: $<$ https://doi.org/10.1016/0022-1759(80)90340-3>. Accessed: Jun. 28, 2021.

PROCHASKA, H. J.; SANTAMARIA, A. B. Direct measurement of $\mathrm{NAD}(\mathrm{P}) \mathrm{H}$ :quinone reductase from cells cultured in microtiter wells: A screening assay for anticarcinogenic enzyme inducers. Analytical Biochemistry, 1988. v.169, p.328-336. Available from: $<$ https://doi. org/10.1016/0003-2697(88)90292-8>.Accessed: Jun. 28, 2021.

RE, R. et al. Antioxidant activity applying an improved abts radical cation decolorization assay. Free Radical Biology \& Medicine, 1999. v.26, p.1231-1237. Available from: $<$ https://doi.org/10.1016/ S0891-5849(98)00315-3>. Accessed: Jun. 28, 2021.

REDDIVARI, L. et al. Grape compounds suppress colon cancer stem cells in vitro and in a rodent model of colon carcinogenesis. BMC Complementary and Alternative Medicine, 2016. v.16, n.1, p.1-12. Available from: <http://dx.doi.org/10.1186/s12906016-1254-2>.Accessed: Jun. 28, 2021.

RODRÍGUEZ-PULIDO, F. J. et al. Preliminary study to determine the phenolic maturity stage of grape seeds by computer vision. Analytica Chimica Acta, 2012. v.732, p.78-82. Available from: <https://doi. org/10.1016/j.aca.2012.01.005>. Accessed: Jun. 28, 2021.

SANTOS, L. P. et al. Phenolic compounds and fatty acids in different parts of Vitis labrusca and V. vinifera grapes. Food Research International, 2011. v.44, p.1414-1418. Available from: <http:// dx.doi.org/10.1016/j.foodres.2011.02.022>. Accessed: Jun. 28, 2021.

SCHERER, R.; GODOY, H. T. Antioxidant activity index (AAI) by the 2,2-diphenyl-1-picrylhydrazyl method. Food Chemistry, 2009. v.112, n.3, p.654-658. Available from: <https://doi. org/10.1016/j.foodchem.2008.06.026>. Accessed: Jun. 28, 2021.

SILVA, M. J. R. Da et al. Yield performance of new juice grape varieties grafted onto different rootstocks under tropical conditions. Scientia Horticulturae, 2018. v.241, p.194-200. Available from: <https://doi. org/10.1016/j.scienta.2018.06.085>. Accessed: Jun. 28, 2021.

SILVA, M. J. R. Da et al. Grape juices produced from new hybrid varieties grown on Brazilian rootstocks - Bioactive compounds, organic acids and antioxidant capacity. Food Chemistry, 2019. v.289, n. March, p.714-722. Available from: $<$ https://doi. org/10.1016/j.foodchem.2019.03.060>.Accessed: Jun. 28, 2021.

SPORN, M. B. Approaches to Prevention of Epithelial Cancer during the Preneoplastic Period. Cancer Research, 1976. v.36, n. July, p.2699-2702. Available from: <https://cancerres.aacrjournals. org/content/36/7_Part_2/2699.long>. Accessed: Jun. 28, 2021.

STEWARD, W. P.; BROWN, K. Cancer chemoprevention: A rapidly evolving field. British Journal of Cancer, 2013. v.109, n.1, p.1-7. Available from: <http://dx.doi.org/10.1038/bjc.2013.280>. Accessed: Jun. 28, 2021.

TECCHIO, M. A. et al. Yield of white and red grapes, in terms of quality, from hybrids and Vitis labrusca grafted on different rootstocks. Scientia Horticulturae, 2020. v.259, p.108846. Available from: <https://doi. org/10.1016/j.scienta.2019.108846>. Accessed: Jun. 28, 2021.

XIAO, H. et al. Quality assessment and discrimination of intact white and red grapes from Vitis vinifera L. at five ripening stages by visible and near-infrared spectroscopy. Scientia Horticulturae, 2018. v.233, n.1, p.99-107. Available from: <https://doi. org/10.1016/j.scienta.2018.01.041>. Accessed: Jun. 28, 2021. 